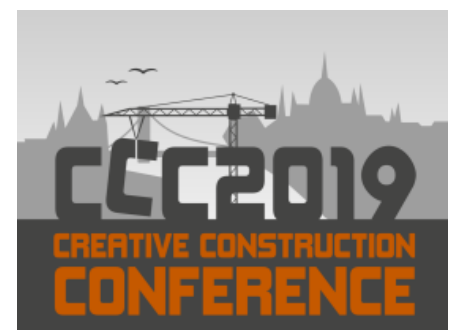

Available online at 2019.creative-construction-conference.com/proceedings/

CCC 2019

Proceedings of the Creative Construction Conference (2019) 098

Edited by: Miroslaw J. Skibniewski \& Miklos Hajdu

https://doi.org/10.3311/CCC2019-098

Creative Construction Conference 2019, CCC 2019, 29 June - 2 July 2019, Budapest, Hungary

\title{
Measures to regain productivity after construction accidents
}

\author{
Florence Y.Y. Ling ${ }^{\mathrm{a}, *}$, Zhe Zhang ${ }^{\mathrm{a}}$, Limin Guo ${ }^{\mathrm{b}}$ \\ ${ }^{a}$ National University of Singapore, School of Design and Environment, 4 Architecture Drive, Singapore 117566 \\ ${ }^{b}$ GS Engineering and Construction Corporation, 8 Temasek Boulevard \#22-05, Singapore 038988
}

\begin{abstract}
When construction accidents occur, besides the direct impact on the victims, there may be collateral effects on the remaining/uninjured workers. In the context of the aftermath of accidents on construction sites, this research investigates the extent to which the uninjured workers' productivity is affected; and uncovers the more effective measures to be instituted on workers after witnessing construction accidents so as to prevent further loss of their productivity. A questionnaire survey was conducted on randomly selected construction professionals who had been supervising workers when and after accidents took place on construction sites in Singapore. The data collected were analyzed using the SPSS software. The first finding is that workers' productivity and wellbeing fall significantly after witnessing construction accidents. They have lower morale, are distressed by the accident and stressed by having to take on additional work or accelerate their work after construction resumes on site. This research found that while a worker's wellbeing deteriorates significantly in the aftermath of a construction accident, there are upsides to construction accidents too. Workers are observed to adopt better work attitude and have higher sense of safety after construction accidents. Significant positive correlation is found between workers' wellbeing and their productivity. The second finding is that the workers turn to fellow workers and supervisors for support post accidents. Relieving them from duties are also effective measures to alleviate the psychological effects of the accidents. The study found that to minimize the negative effects of construction accidents, contractors should improve site safety swiftly, offer employee assistance program, relieve workers from regular duties temporarily and refrain from overloading them after work is allowed to resume. It is recommended that supervisors avail themselves to the workers, for example, through mass psychological debriefing or one-to-one counselling.
\end{abstract}

(C) 2019 The Authors. Published by Budapest University of Technology and Economics \& Diamond Congress Ltd.

Peer-review under responsibility of the scientific committee of the Creative Construction Conference 2019.

Keywords: accidents; morale; productivity; safety; wellbeing

\section{Introduction}

Safety in the construction industry is important as the work environment is prone to accidents [1]. This is especially essential to not only ensure a safe environment for all, but also enable work to be carried out productively [2]. Construction accidents would delay the project [3] and increase project cost [4]. Serious construction accidents also have a negative impact on employees, including physical and psychological effects [5]. Accidents may bring about stress to the workers who witnessed the accident, and wellbeing could be affected [6]. However, there is a lack of research on how accidents affect the wellbeing of workers and the association between workers' wellbeing and workers' productivity.

The aim of the study is to understand the state and association of workers' wellbeing and productivity after witnessing

*Corresponding author: bdglyy@nus.edu.sg 
Ling, Zhang, Guo/ Proceedings of the Creative Construction Conference (2019) 098

https://doi.org/10.3311/CCC2019-098

accidents on site. In the context of the aftermath of accidents on construction sites, the specific objectives are to: investigate the extent to which workers' productivity is affected; examine the state of workers' wellbeing; investigate the association between workers' wellbeing and productivity; and explore the ways in which workers' wellbeing could be enhanced so as to prevent further loss of their productivity.

The scope of this study is limited to construction workers, and their wellbeing and productivity which were observed by their supervisors after reportable injuries/accidents happen on construction projects in Singapore. The reportable injuries are categorized by the Singapore Ministry of Manpower as follows [7]: minor injuries (reportable injuries that did not result in death or major injuries); major injuries (non-fatal injuries, but are more severe in nature); and fatal injuries.

\section{Brief literature review}

Construction accidents have several consequences. The obvious one is the physical injury to the individual or victim. Accidents also have social and financial impacts [8]. The social impacts of site accidents are defined as the effect that would touch the human side; affecting the people revolving around it [8]. The financial impact include direct and indirect costs.

Direct costs arise clearly from the accidents and include medical expenses, compensations and legal costs, while indirect costs are those attributed to lost productivity, time and lower morale [5,7]. An accident can cause a direct loss of production and also wider disruptions in the production process [9], thereby affecting productivity [10].

Workers' wellbeing can be affected by both distress and morale [11]. Distress comes from stressors at work and workers under distress may feel anxious, guilty and sad [11]. The damage to morale has a significant effect on a company's performance [12]. Feeling physically safe is an important factor contributing to morale at work [13]. People working in the construction industry have a high risk of developing post-traumatic stress disorder (PTSD) because unexpected and extreme accidents may happen [14].

The literature review showed that witnessing accidents affect workers' wellbeing. Furthermore, it is known that accidents affect workers' productivity. However, the gap in knowledge is that the link between workers' wellbeing and productivity after witnessing construction accidents is hitherto not known. The extent to which a worker's wellbeing deteriorates after witnessing a construction accident is also not known. The fieldwork is therefore constructed to fill the knowledge gap.

\section{Research method}

The research design is a survey, and data were collected using a specially designed questionnaire. The $\mathrm{Y}$ variable is the extent to which workers' productivity is affected in the aftermath of an accident on site, measured on a 5-point Likert scale ( $1=$ affects very negatively; $5=$ affects very positively). The $\mathrm{X}$ variables are the extent to specific things/attitudes change after an accident on site, measured on a 5 -point Likert scale ( $1=$ change very negatively; $5=$ change very positively). The target population was all construction professionals who had been supervising workers on site at the time and after a construction accident took place. The samples were randomly selected from names listed on Singapore Contractors Association Ltd and Workplace Safety and Health Council's websites. Data was collected via an online survey and analysed using the Statistical Package for Social Sciences (IBM SPSS Statistics 24) software.

\section{Characteristics of sample}

500 emails inviting participation in the survey were sent out and 40 usable responses were collected, giving a response rate of $8 \%$. The characteristics of the respondents are shown in Table 1. The majority of the respondents are male $(85 \%)$. More than half $(52.5 \%)$ of the respondents are contractors (main and subcontractors). Many of them (67.5\%) are in management positions. The majority have more than 10 years of experience in the industry $(82.5 \%)$. The range is 3 to 47 years with a mean of 20.7 years. Most of them have experience in leadership for more than 10 years $(65 \%)$. 
Ling, Zhang, Guo/ Proceedings of the Creative Construction Conference (2019) 098

https://doi.org/10.3311/CCC2019-098

The average years of experience as a leader is 15.1 years. $62.5 \%$ of them are site supervisors, project managers and safety managers who worked closely with workers on site at the time of the accident. The respondents are well placed to inform the research as they had relatively long experience in the industry and as leaders. The findings are more representative of contractors.

Table 1. Profile of Respondents

\begin{tabular}{|c|c|c|}
\hline Description & Frequency & $\%$ \\
\hline \multicolumn{3}{|l|}{ Gender } \\
\hline Female & 6 & 15 \\
\hline Male & 34 & 85 \\
\hline \multicolumn{3}{|l|}{ Main Business } \\
\hline Developer & 2 & 5 \\
\hline Consultant & 7 & 17.5 \\
\hline Main Contractor & 18 & 45 \\
\hline Subcontractor & 3 & 7.5 \\
\hline PM Company & 10 & 25 \\
\hline \multicolumn{3}{|l|}{ Designation } \\
\hline Professional & 13 & 32.5 \\
\hline Mid Management & 18 & 45 \\
\hline Senior Management & 9 & 22.5 \\
\hline \multicolumn{3}{|l|}{ Experience in Industry } \\
\hline $3-10$ years & 7 & 17.5 \\
\hline $11-20$ years & 14 & 35 \\
\hline 21-30 years & 16 & 40 \\
\hline$>30$ years & 3 & 7.5 \\
\hline \multicolumn{3}{|l|}{ Experience as Leader } \\
\hline$<3$ years & 1 & 2.5 \\
\hline 3-10 years & 13 & 32.5 \\
\hline $11-20$ years & 17 & 42.5 \\
\hline 21-30 years & 9 & 22.5 \\
\hline
\end{tabular}

\section{Results and discussion}

Objective 1 is to investigate the extent to which workers' productivity is affected in the aftermath of an accident on site $(\mathrm{Y})$. The results in Table 2 show that for minor accidents $\left(\mathrm{Y}_{\mathrm{a}}\right)$, workers' productivity is not affected significantly (mean $\left.\mathrm{Y}_{\mathrm{a}}=2.93, \mathrm{p}=0.131\right)$. For major accidents $\left(\mathrm{Y}_{\mathrm{b}}=2.65, \mathrm{p}=0.004\right)$ and fatal accidents $\left(\mathrm{Y}_{\mathrm{c}}=2.60, \mathrm{p}=0.031\right)$, workers' productivity levels drop significantly. The findings suggest that as the severity of accidents increases, there is greater productivity loss.

Table 2. Results of One-sample T-test

\begin{tabular}{lllll}
\hline Code & Variable description & Mean & t & Sig. (1-tail) \\
\hline $\mathrm{Y}_{\mathrm{a}}$ & The extent to which workers' productivity is affected in the aftermath of an & 2.93 & -1.138 & 0.131 \\
$\mathrm{Y}_{\mathrm{b}}$ & accident on site & 2.65 & -2.759 & $0.004^{* *}$ \\
$\mathrm{Y}_{\mathrm{c}}$ & & 2.60 & -1.922 & $0.031^{*}$ \\
$\mathrm{X} 1_{\mathrm{a}}$ & The extent to which workers' work attitude changes after a construction accident & 3.20 & 2.082 & $0.022^{*}$ \\
$\mathrm{X} 1_{\mathrm{b}}$ & & 3.48 & 2.276 & $0.014^{*}$ \\
$\mathrm{X} 1_{\mathrm{c}}$ & & 3.60 & 2.306 & $0.013^{*}$
\end{tabular}


Ling, Zhang, Guo/ Proceedings of the Creative Construction Conference (2019) 098 https://doi.org/10.3311/CCC2019-098

\begin{tabular}{lllll}
\hline Code & Variable description & Mean & t & Sig. (1-tail) \\
\hline $\mathrm{X} 2_{\mathrm{a}}$ & The extent to which worker's psychological health changes after a construction & 3.00 & 0.000 & 0.500 \\
$\mathrm{X} 2_{\mathrm{b}}$ & accident & 2.85 & -0.771 & 0.223 \\
$\mathrm{X} 2_{\mathrm{c}}$ & & 2.90 & -0.392 & 0.349 \\
$\mathrm{X} 3_{\mathrm{a}}$ & The extent of workers' distress after a construction accident. (eg. anxiety, pain, or & 4.20 & -6.150 & $0.000^{* *}$ \\
$\mathrm{X} 3_{\mathrm{b}}$ & sorrow) & 3.10 & -12.577 & $0.000^{* *}$ \\
$\mathrm{X} 3_{\mathrm{c}}$ & & 2.23 & -14.521 & $0.000^{* *}$ \\
$\mathrm{X} 4_{\mathrm{a}}$ & Workers' sense of safety level of the workplace after a construction accident & 3.18 & 1.862 & $0.035^{*}$ \\
$\mathrm{X} 4_{\mathrm{b}}$ & & 3.73 & 4.223 & $0.000^{* *}$ \\
$\mathrm{X} 4_{\mathrm{c}}$ & & 4.08 & 5.276 & $0.000^{* *}$ \\
$\mathrm{X} 5_{\mathrm{a}}$ & The extent to which workers' stress level is affected when they undertake & 2.90 & -2.082 & $0.022^{*}$ \\
$\mathrm{X} 5_{\mathrm{b}}$ & additional work after a construction accident & 2.63 & -3.204 & $0.001^{* *}$ \\
$\mathrm{X} 5_{\mathrm{c}}$ & & 2.53 & -2.829 & $0.004^{* *}$ \\
$\mathrm{X} 6_{\mathrm{a}}$ & The extent to which worker's morale is affected after a construction accident & 2.88 & -1.706 & $0.048^{*}$ \\
$\mathrm{X} 6_{\mathrm{b}}$ & & 2.45 & -3.731 & $0.000^{* *}$ \\
$\mathrm{X} 6_{\mathrm{c}}$ & & 2.13 & -4.242 & $0.000^{* *}$ \\
\hline
\end{tabular}

Notes: Subscripts a, b and c refer to minor, major and fatal accidents respectively. ${ }^{*} p<0.05 ; * * p<0.01$.

Objective 2 is to examine workers' wellbeing in the aftermath of an accident on site. Table 2 shows that they become significantly distressed (X3), experience significant stress when having to take on additional work after the accident (X5), and have significantly lower morale (X6). On the positive side, their work attitudes (X1) improve and sense of safety level (X4) increases after accidents.

Objective 3 is to investigate the association between workers' wellbeing and productivity after accidents. Table 3 presents the significant correlations between workers' productivity $(\mathrm{Y})$ and workers' wellbeing variables $(\mathrm{X})$ in the aftermath of an accident on site. The results show a significant positive correlation between workers' attitude (X1) and workers' productivity in the aftermath of an accident on site (Y) for all 3 categories of accidents, suggesting positive changes after workers learn from new experiences.

Table 3. Significant Correlations with Productivity

\begin{tabular}{|c|c|c|c|c|c|c|}
\hline \multirow{2}{*}{$\begin{array}{l}\text { Variable } \\
\text { Code }\end{array}$} & \multicolumn{2}{|c|}{ Minor accident $\left(\mathrm{Y}_{\mathrm{a}}\right)$} & \multicolumn{2}{|c|}{ Major accident $\left(\mathrm{Y}_{\mathrm{b}}\right)$} & \multicolumn{2}{|c|}{ Fatal accident $\left(\mathrm{Y}_{\mathrm{c}}\right)$} \\
\hline & $\mathrm{r}$ & Sig & $\mathrm{r}$ & Sig & $\mathrm{r}$ & Sig \\
\hline $\mathrm{X} 1$ & 0.567 & $0.000^{* *}$ & 0.403 & $0.010^{*}$ & 0.540 & $0.000^{* * *}$ \\
\hline X2 & 0.616 & $0.000^{* *}$ & 0.595 & $0.000^{* *}$ & 0.825 & $0.000^{* * *}$ \\
\hline X3 & 0.419 & $0.007 * *$ & - & - & - & - \\
\hline $\mathrm{X} 4$ & 0.468 & $0.002^{* *}$ & - & - & - & - \\
\hline $\mathrm{X} 5$ & 0.344 & $0.030 *$ & 0.421 & $0.007^{* *}$ & 0.576 & $0.000^{* *}$ \\
\hline X6 & - & - & 0.662 & $0.000^{* *}$ & 0.508 & $0.001^{* *}$ \\
\hline
\end{tabular}

Table 3 shows a significant positive correlation between workers' psychological health (X2) and workers' productivity $(\mathrm{Y})$ in the aftermath of an accident on site. This suggests that when workers' psychological health deteriorates, productivity loss is likely to take place, regardless of the severity of the accident.

In the aftermath of an accident on site, workers experience significant distress (X3) such as anxiety, pain or sorrow, and their distress worsens as the severity of accidents increases from minor to major to fatal (see Table 2, means X3 $3_{\mathrm{a}}=$ 
Ling, Zhang, Guo/ Proceedings of the Creative Construction Conference (2019) 098

https://doi.org/10.3311/CCC2019-098

$4.2, \mathrm{X}_{\mathrm{b}}=3.10$ and $\left.\mathrm{X} 3_{\mathrm{c}}=2.23\right)$. Significant positive correlation is found between distress in workers $\left(\mathrm{X} 3_{\mathrm{a}}\right)$ and workers' productivity (Y) when minor accidents happen (see Table 3) suggesting that when workers' distress becomes more serious, workers' productivity is affected negatively.

There is a significant positive correlation between workers' perceptions of workplace safety $\left(\mathrm{X} 4_{\mathrm{a}}\right)$ and workers' productivity after minor accidents happen $\left(\mathrm{Y}_{\mathrm{a}}\right)$ (see Table 3 ). This may be explained by improvement in site safety after construction accidents happen.

The remaining workers on site may be asked to cover the duties of accident victims. The results show that having to take on additional work increases stress level of these workers, and the stress worsens as the severity of accidents increases (see Table 2, means decrease from $2.90\left(\mathrm{X}_{\mathrm{a}}\right)$ to $2.63\left(\mathrm{X}_{\mathrm{b}}\right)$ to $2.53\left(\mathrm{X} 5_{\mathrm{c}}\right.$ ) as accident severity moves from minor to major to fatal). The extent of stress brought about to the remaining workers on site from having to do additional work (X5) is significantly and positively correlated with workers' productivity (Y) for all three categories of accidents (see Table 3).

As the severity of accidents increases, workers' morale is affected more negatively (see Table 2, means decrease from $2.88\left(\mathrm{X6}_{\mathrm{a}}\right)$ to 2.45 ( $\left.\mathrm{X}_{\mathrm{b}}\right)$ to 2.13 (X6 ${ }_{\mathrm{c}}$ ) as accident severity moves from minor to major to fatal). The morale of workers (X6) is significantly correlated with workers' productivity (Y) in major and fatal accidents (see Table 3).

\section{Recommendations}

The research asked respondents what actions are taken by workers or their employers after witnessing construction accidents. To seek solace, $95 \%$ and $83 \%$ turn to peers and supervisors respectively. $40 \%$ turn to family members. About $55 \%$ of the contractors relieved workers from their duties temporarily and $35 \%$ referred workers to professionals to alleviate psychological effects in the aftermath of accidents. The majority of workers were required to cover the duties of victims.

It is recommended that after an accident, contractors should swiftly improve their safety management system. The improved site safety may give workers peace of mind and enable them to work productively. Improving workers' morale (X6) after major and fatal accidents may lead to higher productivity (see Table 3). This suggests that contractors should set aside time for workers to commiserate with each other. Supervisors should avail themselves to listen to the workers after accidents occur. For fatal accidents, it is recommended that contractors offer workers access to counsellors so as to improve their psychological health.

Construction accidents affect workers' psychological health (see X2 in Table 2). It is recommended that workers be relieved from duties, and given time off in order to recover from the psychological shock. It is not recommended that workers who witnessed the accident be asked to over the work of the accident victims immediately as the longer term negative effect of stress and low morale outweigh the need to complete the project in a timely manner.

\section{Conclusion}

The results show that workers' productivity fall significantly after witnessing major and fatal accidents (see Table 2). Workers' wellbeing is significantly affected after construction accidents. They have lower morale, greater distress and higher stress level (see Table 2). However, there are positive changes to their work attitude and perceptions of workplace safety.

This study contributes to knowledge by showing that there is a significant positive correlation between wellbeing and productivity of workers in the aftermath of construction accidents (see Table 3). As wellbeing deteriorates, productivity also declines. It is recommended that in the aftermath of construction accidents, employers should focus on improving workers' wellbeing as this may bring the productivity up again. It is suggested that workers be offered employee assistance programs to improve their psychological health and morale. Contractors should quickly improve their safety management system on site. They should refrain from assigning workers with additional work which was originally the victims' work or to catch up with the schedule, as these contribute negatively to workers' productivity. 
Ling, Zhang, Guo/ Proceedings of the Creative Construction Conference (2019) 098

https://doi.org/10.3311/CCC2019-098

\section{References}

[1] F. Yilmaz, U.B. Çelebi, The importance of safety in construction sector: Costs of occupational accidents in construction sites, Business and Economics Research Journal 6(2) (2015) 25-37.

[2] E.C. Lim, J. Alum, Construction productivity: Issues encountered by contractors in Singapore, International Journal of Project Management 13(1) (1995) 51-58. https://doi.org/10.1016/0263-7863(95)95704-H

[3] Z. Kadiri, T. Nden, G. Avre, T. Oladipo, A. Edom, P. Samuel, G. Ananso, Causes and effects of accidents on construction sites (A case study of some selected construction firms in Abuja, FCT Nigeria), IOSR Journal of Mechanical and Civil Engineering 11(5) (2014), 66-72. https://doi.org/10.9790/1684-11516672

[4] W. Asanka, M. Ranasinghe, Study on the impact of accidents on construction projects, in: 6th International Conference on Structural Engineering and Construction Management, Kandy, Sri Lanka, (2015, 11th-13th December) 58-67.

[5] T.C. Haupt, K. Pillay, Investigating the true costs of construction accidents, Journal of Engineering, Design and Technology 14(2) (2016) 373-419. https://doi.org/10.1108/JEDT-07-2014-0041

[6] A.C. McFarlane, R.A. Bryant, Post-traumatic stress disorder in occupational settings: Anticipating and managing the risk, Occupational Medicine 57(6) (2007) 404-410. https://doi.org/10.1093/occmed/kqm070

[7] Workplace Safety and Health Institute, Workplace Safety and Health Report, Ministry of Manpower, Singapore, 2015.

[8] D. Mthalane, A. Othman, R. Pearl, The economic and social impacts of site accidents on the South African society, in: Proceedings of the 5th Post Graduate Conference on Construction Industry Development, Bloemfontein South Africa, 2008, 1-10.

[9] P. Böckerman, P. Ilmakunnas, The job satisfaction-productivity nexus: A study using matched survey and register data, ILR Review 65(2) (2012) 244-262. https://doi.org/10.1177\%2F001979391206500203

[10] Z. Mao, B.H. Goh, S.Q. Wang, G. Ofori, Total factor productivity growth accounting in the construction industry of Singapore, Construction Management and Economics 21(7) (2003) 707-718. https://doi.org/10.1080/0144619032000056126

[11] P. Cotton, P.M. Hart, Occupational wellbeing and performance: A review of organizational health research, Australian Psychologist 38(2) (2003) 118-127. https://doi.org/10.1080/00050060310001707117

[12] Y. Feng, E.A.L. Teo, F.Y.Y. Ling, S.P. Low, Exploring the interactive effects of safety investments, safety culture and project hazard on safety performance: An empirical analysis, International Journal of Project Management 32(6) (2014) 932-943.

[13] M. Behm, Employee morale examining the link to occupational safety and health, Professional Safety 54(10) (2009) 42-49.

[14] M.A. Perrin, L. DiGrande, K. Wheeler, L. Thorpe, M. Farfel, R. Brackbill, Differences in PTSD prevalence and associated risk factors among World Trade Center disaster rescue and recovery workers, American Journal of Psychiatry 164(9) (2007) 1385-1394. https://doi.org/10.1176/appi.ajp.2007.06101645 